\title{
Prune belly and schizencephaly
}

\section{Figure T1-weighted MRI and a photograph of the characteristic abdomen}
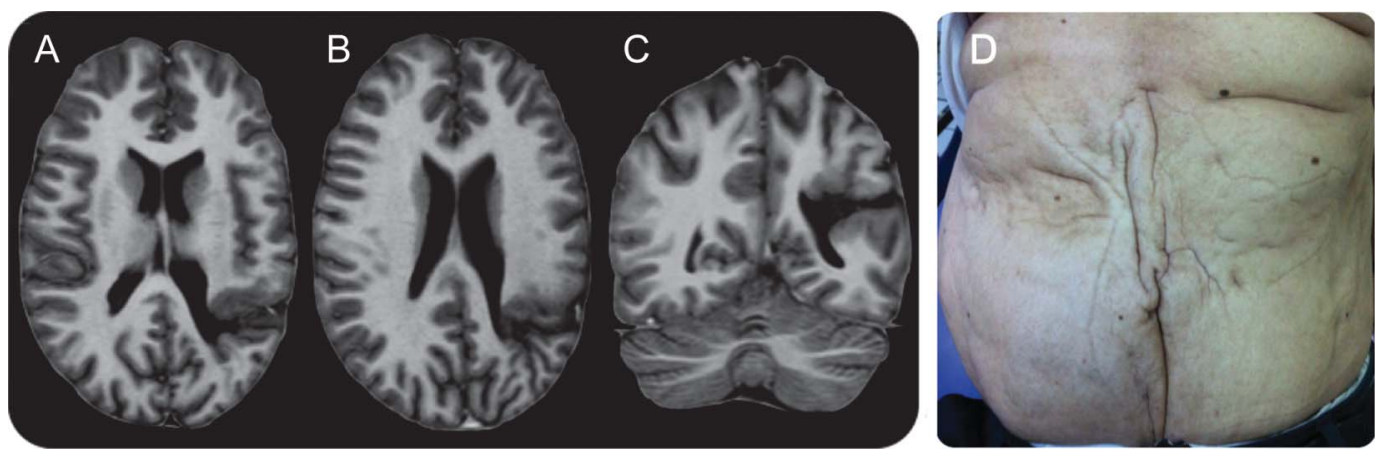

(A-C) Discrete global brain atrophy, ventricular system asymmetry, left hemisphere schizencephaly, and bilateral heterotopias. (D) Wrinkly folds of skin covering the abdomen due to thin abdominal wall muscles, a major feature of the prune belly syndrome.

A 45-year-old man without relevant family history presented with prune belly syndrome (PBS). ${ }^{1}$ He had a 34year history of right simple partial motor seizures with and without secondary generalization, with a good response to carbamazepine monotherapy; there was no cognitive or social impairment. MRI showed global brain atrophy, ventricular asymmetry, left hemisphere schizencephaly, and bihemispheric heterotopias (figure, A-C). Although PBS is considered a mesoderm layer defect characterized by total or partial absence of abdominal muscles (figure, D), urinary tract abnormalities, and cryptorchidism of unknown etiology, involvement of other embryologic tissues has also been reported, including the ectodermic layer, as in this case. ${ }^{1,2}$

Guillermo A. Navarro-Arenas, MD, Diego R. Orozco-Valera, MD, Erwin Chiquete, MD, PhD,

José L. Ruiz-Sandoval, MD

From the Hospital Civil de Guadalajara "Fray Antonio Alcalde" (G.A.N.-A., D.R.O.-V., J.L.R.-S.); the Centro Universitario de Ciencias de la Salud (J.L.R.-S.), Universidad de Guadalajara; and the Instituto Nacional de Ciencias Médicas y Nutrición Salvador Zubirán (E.C.), Mexico City, Mexico.

Author contributions: Dr. Navarro-Arenas: drafting/revising the manuscript, study concept or design, analysis or interpretation of data, accepts responsibility for conduct of research and final approval. Dr. Orozco-Valera: drafting/revising the manuscript, study concept or design, accepts responsibility for conduct of research and final approval. Dr. Chiquete: drafting/revising the manuscript, accepts responsibility for conduct of research and final approval. Dr. Ruiz-Sandoval: drafting/revising the manuscript, accepts responsibility for conduct of research and final approval, acquisition of data.

Study funding: No targeted funding reported.

Disclosure: The authors report no disclosures relevant to the manuscript. Go to Neurology.org for full disclosures.

Correspondence to Dr. Ruiz-Sandoval: jorulej-1nj@prodigy.net.mx

1. Tonni G, Ida V, Alessandro V, Bonasoni MP. Prune-belly syndrome: case series and review of the literature regarding early prenatal diagnosis, epidemiology, genetic factors, treatment, and prognosis. Fetal Pediatr Pathol 2013;31:13-24.

2. Heffner RR. Syndrome of absent abdominal muscles: two cases with microcephaly, polymicrogyria, and cerebellar malformations. J Neurol Neurosurg Psychiatry 1970;33:844-850. 


\section{Neurology}

Prune belly and schizencephaly

Guillermo A. Navarro-Arenas, Diego R. Orozco-Valera, Erwin Chiquete, et al. Neurology 2014;83;665

DOI 10.1212/WNL.0000000000000687

\section{This information is current as of August 11, 2014}

\section{Updated Information \&} Services

References

Subspecialty Collections

Permissions \& Licensing

Reprints including high resolution figures, can be found at: http://n.neurology.org/content/83/7/665.full

This article cites 2 articles, 1 of which you can access for free at: http://n.neurology.org/content/83/7/665.full\#ref-list-1

This article, along with others on similar topics, appears in the following collection(s):

Cortical dysplasia

http://n.neurology.org/cgi/collection/cortical_dysplasia

Cortical localization

http://n.neurology.org/cgi/collection/cortical_localization

Epileptogenic zone

http://n.neurology.org/cgi/collection/epileptogenic_zone

Information about reproducing this article in parts (figures,tables) or in its entirety can be found online at:

http://www.neurology.org/about/about_the_journal\#permissions

Information about ordering reprints can be found online:

http://n.neurology.org/subscribers/advertise

Neurology ${ }^{\circledR}$ is the official journal of the American Academy of Neurology. Published continuously since 1951, it is now a weekly with 48 issues per year. Copyright @ 2014 American Academy of Neurology. All rights reserved. Print ISSN: 0028-3878. Online ISSN: 1526-632X.

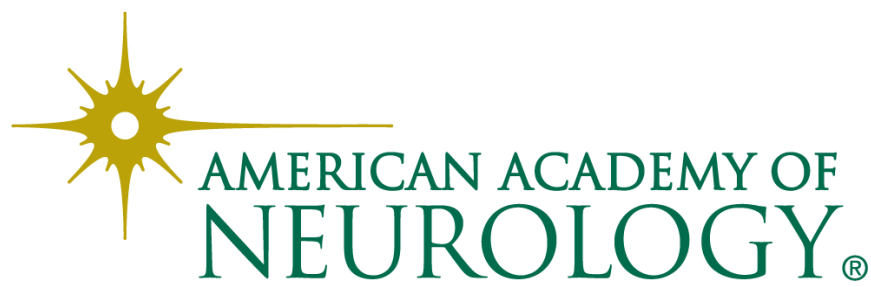

